\title{
GROWTH OF DIFFERENT FRUIT TREE SPECIES IN SILVOPASTORAL SYSTEMS DURING THE ESTABLISHMENT PHASE ${ }^{1}$
}

\author{
CAROLINA DELLA GIUSTINA ${ }^{2 *}$, ROBERTA APARECIDA CARNEVALLI ${ }^{3}$, MARCELO RIBEIRO ROMANO $^{3}$, \\ DIEGO BARBOSA ALVES ANTONIO ${ }^{3}$, CAMILA ECKSTEIN ${ }^{2}$
}

\begin{abstract}
The benefits of integrating agricultural components into silvopastoral systems are widely known, but the limited knowledge about ecological processes in the establishment phase impedes the use of this technology. The objective of this study was to evaluate interactions between fruit tree species and the sward layer under canopies of trees in the establishment phase of silvopastoral systems in Mato Grosso, Brazil. The experiment was implemented in October 2013, with an evaluation period from January to July 2015. The systems were composed of eight fruit trees intercropped with Tifton 85 grass. A completely randomized block design was adopted, with two replications per area per treatment. We evaluated the agronomic performance of the fruit trees, the categories of the light environment, and the plant accumulation under the canopies. The acerola fruit trees of the variety Roxinha had higher Leaf area index (LAI) and Light interception (LI) values, showing a denser canopy with small porosity and the lowest light quality available to the plants beneath the canopy (lower red/far-red ratio), thereby decreasing plant accumulation under trees. The guava fruit trees showed higher growth rates than the other fruit trees, but lower LAI and LI values and a higher red/far-red ratio, allowing higher plant growth under the canopy. Cajá trees showed a similar behavior; however, this species is deciduous, which limits its potential use in integrated systems. Banana and coconut trees were highly dependent on irrigation during the dry season. The remaining species showed an adequate growth and potential to control plant species growth under their canopies.
\end{abstract}

Keywords: Plant competition. Intercropping. Light environment.

\section{CRESCIMENTO DE ESPÉCIES DE ÁRVORES FRUTÍFERAS DIFERENTES EM SISTEMAS SILVIPASTORIL DURANTE A FASE DE ESTABELECIMENTO}

\begin{abstract}
RESUMO - Os benefícios de integrar os componentes agrícolas já são bastante conhecidos, porém o conhecimento sobre os processos ecológicos da competição das plantas ainda é uma barreira para essa tecnologia. $\mathrm{O}$ objetivo deste estudo foi avaliar a interação entre espécies fruteiras e a vegetação sob suas copas na fase de estabelecimento de sistemas silvipastoris no Mato Grosso, Brasil. O experimento foi implantado em 2013 e avaliado em 2015. Estes sistemas foram compostos por oito espécies de fruteiras consorciadas com Tifton-85. O delineamento experimental foi em blocos completos casualizados com duas repetições de área por tratamento. Foi avaliado o desempenho agronômico das espécies fruteiras, caracterização do ambiente luminoso e o acumulo de material vegetal sob as copas. A aceroleira Roxinha apresentou os maiores valores de índice de área foliar (IAF) e interceptação luminosa (IL) devido a um dossel mais denso com baixa porosidade e a menor qualidade de luz disponível sob as copas das árvores (menor relação vermelho/vermelho distante $-\mathrm{V} / \mathrm{Vd}$ ), condicionando a uma redução no acúmulo de material vegetal sob as copas. As goiabeiras cresceram mais do que as outras espécies, contudo apresentaram os menores valores de IAF e IL e alta relação $\mathrm{V} / \mathrm{Vd}$, permitindo a presença de mais plantas sob sua copa. Cajazeira demonstrou resposta similar, contudo esta espécie é decídua, podendo apresentar um potencial mais limitado em sistemas integrados. Bananeira e coqueiro mostraram uma grande dependência de irrigação durante a estação seca. As demais espécies apresentaram um crescimento adequado e potencial para controlar o crescimento das plantas sob suas copas.
\end{abstract}

Palavras-chaves: Competição. Consórcio. Ambiente luminoso.

\footnotetext{
${ }^{*}$ Corresponding author

${ }^{1}$ Received for publication in 05/05/2016; accepted in 02/14/2017.

Paper extracted from the Master's dissertation of the first author, funded by FAPEMAT and Capes.

${ }^{2}$ Institute of Agricultural and Environmental Sciences, Universidade Federal do Estado de Mato Grosso, Sinop, MT, Brazil; carolgiustina@hotmail.com, camila.eckstein@gmail.com.

${ }^{3}$ Embrapa Agrossilvipastoril, Empresa Brasileira de Pesquisa Agropecuária, Sinop, MT, Brazil; roberta.carnevalli@embrapa.br, marcelo.romano@embrapa.br, diego.antonio@embrapa.br.
} 


\section{INTRODUCTION}

The benefits of integrating agricultural components into silvopastoral systems are widely known. In addition to providing and/or increasing the shaded area available to animals, silvopastoral systems allow a reduction of heat stress on animals, thereby improving their welfare and contributing to improved environmental conditions (TUCKER; ROGERS; SCHÜTZ, 2008; BALBINO; BARCELLOS; STONE, 2011).

Further, the presence of trees in pastoral systems improves soil chemical, physical, and biological attributes, mainly through increased organic matter compounds, improved nutrient cycling, and better protection against erosion, making silvopastoral systems more efficient in the use of water, light, and nutrients (MELOTTO; NICODEMO; BOCCHESE, 2009; FEY; MALAVASI; MALAVASI, 2015). As a result, pasture degradation processes can be largely avoided (PACIULLO et al., 2011).

Silvopastoral systems also contribute to the mitigation of greenhouse gas emissions. Trees have a high ability to sequester carbon and produce a plant litter more resistant to decomposition, which makes silvopastoral systems more efficient in terms of carbon fixation than single systems. Because of the combination of more than one component, silvopastoral systems typically increase and diversify the income of the producer through the generation of product variety of marketable products (wood, fruits, seeds, etc.), providing greater economic stability and sustainability.

However, the integration of trees and the consequent competition for light (both quantitively and qualitatively) may promote reduced dry matter production under the canopy. Because of the differential absorption of the wavelengths of the light spectrum by different species, the light quality is altered. When the light penetrates the upper vegetation layer, composed of the canopy of the forest component, the red light is reduced as a result of the preferential absorption of these wavelengths by the upper leaves, leaving large quantities of the far-red light spectrum. Because the far-red light (FR) is not absorbed, the red: far-red light (R: FR) ratio under the forage sward is modified (TAIZ; ZEIGER, 2010), with higher far-red levels reaching the plants. This can also be observed for blue light. Such changes can significantly impact the production and morphology of a variety of plants under shading.

Despite the advances achieved in research related to integrated systems in the last few years, the scientific knowledge of integrated production and operation of such systems still falls short of the demanded quantity. The success of an integrated system depends strongly on planning and good establishment. Proper implementation depends, among several factors, on the combination of plants, adaptability of the integration, initial growth rates of the trees, and their ability to dominate the area, reducing the time spent for manual control of the forage and allowing their coexistence with animals.

Therefore, the objective of this study was to evaluate the influence of fruit tree growth on the control of the sward growth (forage and invasive plants) under the tree canopies in the phase of implementation of silvopastoral systems used in the post-weaning stages of dairy heifers in the State of Mato Grosso, Brazil.

\section{MATERIAL AND METHODS}

The experiment was carried out at Embrapa Agrosilvopastoral, located in Sinop-MT, Brazil

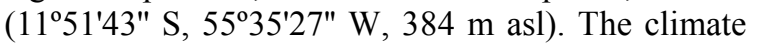
of the region is classified as a tropical humid or sub-humid Am type (Köppen), with an average annual temperature of $25^{\circ} \mathrm{C}$, relative air humidity of $76 \%$, and precipitation of 2,020 $\mathrm{mm}$ (INMET, 2014). The soil was classified as a Typic Hapludox, clayey, caulinitic, isothermic (SOIL SURVEY STAFF, 1999), of flat relief.

The experiment was implemented in October 2013 by planting the fruit trees and the Tifton 85 grass. The evaluation period was from January 2015 to July 2015, representing the final period of the establishment phase when the differences between plants were evident until dry season.

Average precipitation during the experimental period varied largely in relation to the historical average of the previous 30 years, which classifies the experimental period as atypical. February had the greatest accumulated precipitation of the year $(430 \mathrm{~mm})$, followed by March $(355 \mathrm{~mm})$, whereas in the other months, precipitation was below $150 \mathrm{~mm}$, ceasing completely in June. January received $172 \mathrm{~mm}$ less precipitation than the historical average, whereas in the period from February to March, values higher than the 30 -years average were observed.

The experimental site covered an area of 3.75 ha. Within this area, eight silvopastoral systems were distributed, composed of eight fruit trees intercropped with Tifton 85 (Cynodon spp), as follows: cajá (Spondias mombin), red guava (Psidium guajava) cv. Paluma, cashew (Anacardium occidentale) var. Embrapa 51 (EMB51) and var. CCP 76, acerola (Malpighia glabra) var. Roxinha and var. Sertaneja, dwarf green coconut (Cocos nucifera L.), and banana (Musa spp.) var. Williams.

A completely randomized block design was adopted, with two replications per area per treatment. Each 1,650- $\mathrm{m}^{2}$ experimental unit received different numbers of fruit tree seedlings, according to the canopy architecture and the spacing recommended for single cultivation. The plots with cajá, coconut, guava trees, and the two cashew varieties received 
27 plants with a spacing of $4 \times 10 \mathrm{~m}$. The plots with banana trees and the two acerola cultivars received 36 plants distributed in a double center row with a spacing of $4 \times 4 \times 10 \mathrm{~m}$. To avoid edge effects, we only evaluated the central plants in the inter-rows.

The planted fruit tree seedlings had a similar age (6 months), size (between 30 and $50 \mathrm{~cm}$ in height), and stem diameter (less than $1 \mathrm{~cm}$ ). Data collection was started when the fruit trees were 15 months old. The forage was planted using seedlings after allocation, correction, furrowing, fertilization, and planting of the fruit tree species. In the first year, the pasture was managed by mechanical cuts whenever it reached a height of $50 \mathrm{~cm}$, which was necessary because animals could not enter the area with young trees in the establishment phase. Small animals, such as calves, can only enter such areas when the tree trunk diameters are larger than $60 \mathrm{~mm}$. The pasture was fertilized with $40 \mathrm{~kg} \mathrm{~N}$ per ha (urea) and $25 \mathrm{~kg} \mathrm{P}$ per ha (simple superphosphate) for each plot. The fruit trees received an individual fertilization in the planting hole of $150 \mathrm{~g}$ of simple superphosphate, $300 \mathrm{~g}$ of limestone, 20 liters of tanned cattle manure, $50 \mathrm{~g}$ of micronutrients and natural phosphate. Natural phosphate application varied according to the species: $750 \mathrm{~g}$ to cashew and coconut fruit trees, $200 \mathrm{~g}$ to acerola and cajá fruit trees, and $450 \mathrm{~g}$ to red guava and banana fruit trees. The top dressing also varied between the species (acerola, cashew and red guava: $300 \mathrm{~g}$ ammonium sulphate and $75 \mathrm{~g}$ potassium chloride; cajá: $100 \mathrm{~g}$ ammonium sulphate and $50 \mathrm{~g}$ potassium chloride; banana: $375 \mathrm{~g}$ ammonium sulphate and $190 \mathrm{~g}$ potassium chloride, and coconut: 1,700 g ammonium sulphate and $592 \mathrm{~g}$ potassium chloride). Maintenance fertilization was performed between January and March 2015. Banana, red guava, cajá, and cashew trees received $500 \mathrm{~g}$ ammonium sulphate, $250 \mathrm{~g}$ of simple superphosphate, and $150 \mathrm{~g}$ of potassium chloride per tree. Acerola trees received $200 \mathrm{~g}$ ammonium sulphate, $250 \mathrm{~g}$ simple superphosphate and $150 \mathrm{~g}$ potassium chloride per tree, and coconut trees received 1,000 g ammonium sulphate, $600 \mathrm{~g}$ simple superphosphate, and $500 \mathrm{~g}$ potassium chloride per tree. The top dressing was divided in three applications to the soil and under the canopies.

In this study, we evaluated the agronomic performance of the fruit trees, categorization of the light environment, and plant accumulation under the canopies.

\section{Agronomic performance of fruit trees}

The agronomic performance of the fruit trees was evaluated by monitoring plant height and canopy diameter every two months.

A 3-m graduated ruler was used to evaluate tree height by measuring the distance from the base (soil level) to the top of the canopy. In the case of banana trees, the reference was the point of origin of the last emerged leaf.

To evaluate canopy diameter, measurements were taken from the beginning to the end of the canopy of the trees, following the orientation of the row and that of the inter-row (except for the coconut and banana trees) and calculating the average value (see SOUZA et al., 2006). As the coconut and banana trees had more regular canopies, we adapted the methodology, measuring the 3rd completely expanded leaf with a measuring tape and calculating the diameter from the radius. With the obtained canopy diameter values, we calculated the canopy perimeter, using the following formula:

Canopy perimeter $(\mathrm{cm})=\mathrm{D}^{*} \pi$, where $\mathrm{D}$ is the canopy diameter $(\mathrm{cm})$.

To calculate canopy volume, the proportion of canopy height was determined by using the trunk height, taken from the neck of the plant to the beginning of the canopy. With the obtained plant height and trunk height data, a canopy height proportion of $1 / 3$ was adjusted for the banana trees and a proportion of $2 / 3$ for the other species. Using the canopy diameter and canopy proportion data, we calculated canopy volume, using the following formula:

For the banana tree:

Volume $\left(m^{3}\right)=1 / 3 * D^{2 *} \pi * h$

For the other species:

Volume $\left(\mathrm{m}^{3}\right)=2 / 3 * \mathrm{D}^{2 *} \pi^{*} \mathrm{~h}$

where $\mathrm{D}$ is the canopy diameter $(\mathrm{cm})$ and $\mathrm{h}$ is the plant height $(\mathrm{cm})$.

\section{Characterization of the light environment}

Light interception (LI) and its corresponding leaf area index (LAI) under the tree canopies were measured monthly with a sward analyzer (LAI-2200, Licor $\left.^{\circledR}\right)$. The first reading was taken in a point in the open air near the tree to be evaluated in order to characterize the incident light on the tree; subsequently, eight points beneath the canopy were evaluated, divided into imaginary quadrants (four points near the trunk and four between the trunk and the end of the canopy). Evaluations were undertaken in the early morning or late afternoon when the sun was approaching the horizon line.

The quality of the light under the canopies was measured monthly with a portable spectrometer (SpectraPen SP-100). Two pre-selected representative trees were used for this evaluation. The device was positioned vertically at the trunk under the canopy, on the projection of the shadow. The evaluation period was between 08:00 and 10:00 h.

\section{Plant material accumulation under canopies}

Accumulation of plant material was measured 
monthly by cutting the entire plant material in a previously defined radius, using a buried grass delimiter that allowed only one centimeter to remain above the soil surface. The delimited area was located one meter from the trunks of the center trees, totaling an area of $3.14 \mathrm{~m}^{2}$ under each canopy, in which intense competition occurs between the trees and the other vegetation components. The material was collected and weighed on a portable digital scale to determine total fresh matter production. Still in the field, the material was sub-sampled, weighed, and subsequently taken to the Plant Physiology Laboratory of Embrapa Agrosilvopastoral, where the samples were dried in a forced-air oven at $55^{\circ} \mathrm{C}$ for three days to determine dry weight. Based on the fresh and dry weights of the sub-samples, we obtained the total dry matter yield data.

\section{Statistical Analysis}

The data were subjected to Kolmogoroff-Smirnoff-based normality tests to evaluate data distribution via a normal PROC univariate procedure. Analysis of variance was performed using the PROC Mixed procedure. Means were compared using PDIFF at 5\% probability. All analyses were performed using SAS 9.2.

\section{RESULTS AND DISCUSSION}

The seedlings were planted in October 2013 in adequate water conditions; irrigation was performed during the first and second dry season to stimulate growth. At the beginning of the experiment, the trees had a trunk diameter of less than $1 \mathrm{~cm}$ and a height of less than $30 \mathrm{~cm}$. In June 2014, each fruit tree had a trunk diameter of around $2 \mathrm{~cm}$ and a height of around $100 \mathrm{~cm}$; banana trees had reached a height of $140 \mathrm{~cm}$. The trees provided significant shading and dominated the vegetation at the beginning of the data collection period in the wet season in 2015.

Guava trees showed the greatest height $(p=0.0003)$, perimeter, and canopy volume $(p<0.0001)$ in July 2015, the final month of the assessments, compared with the other established species. In contrast, coconut trees had the lowest height and canopy volume levels. The coconut tree canopy volume did not differ from those of the banana and cajá trees at the end of the evaluated period. The cajá trees, despite having an intermediate plant height, had the lowest canopy perimeter at the end of the experiment, as they had lost most of their leaves (Table 1).

Guava trees showed highest growth rates when intercropped with Tifton 85, although the initial establishment might have been impaired by the grass. In a similar study, Paiva et al. (2005) have evaluated a polyculture system of guava cv. Paluma with nine other species; at 12 months, the guava had reached a height of $229 \mathrm{~cm}$. In our experiment, guava trees reached a height of $165 \mathrm{~cm}$ at 15 months, probably as a result of low soil fertility or competition among plants. The cashew variety CCP76 showed a less significant difference $(94 \mathrm{~cm})$ in plant height when compared with the results of Paiva et al. (2005) $(109 \mathrm{~cm})$.

Despite showing a higher canopy perimeter than the other tree species in January (Table 1), banana trees had an intermediate height, causing low canopy-volume values. This low canopy volume characteristic is also due to the architecture of the plant, since the banana pseudostem occupies around $2 / 3$ of the total plant height, whereas in the other species, the trunk corresponds to $1 / 3$ of the total height. In spite of the expressive increase in banana tree height in the period from January $(84 \mathrm{~cm})$ to July $(147 \mathrm{~cm})(p<0.0001)$ and in canopy perimeter from January $(613 \mathrm{~cm})$ to May $(878 \mathrm{~cm})$ $(p<0.0001)$, there was a sharp decrease to $407 \mathrm{~cm}$ at the end of the evaluation period (Table 1). Thus, the banana, cajá, and coconut trees showed the lowest canopy volumes in July, i.e., the lowest shading ability and competition (Table 1).

In the case of the banana trees, the reduction of the canopy perimeter and, consequently, the reduction of volume, can be explained by the low maintenance of leaves; frequently, there was only one live leaf per plant. This decrease in the number of live leaves might have been caused by three factors: i) water deficit, as the root system of the banana tree is relatively more superficial (clayey soils, where roots concentrate at a depth of $0.50 \mathrm{~m}$ and approximately $50 \%$ at $0.60 \mathrm{~m}$ from the pseudostem (SILVA et al., 2009)), thereby suffering drought in relation to the other species; ii) Sigatoka, a leaf disease to which the variety Willians is susceptible, caused by the pathogen Mycosphaerella fijiensis and reducing the leaf area index; iii) increased maximum wind speed in July $\left(8.28 \mathrm{~m} \mathrm{~s}^{-1}\right)$, which might have caused irreversible leaf damage, esp. as the seedlings were not planted at a high density. 
C. D. GIUSTINA et al.

Table 1. Canopy height, canopy diameter, and canopy volume of fruit tree species in silvopastoral systems during the experimental period.

\begin{tabular}{|c|c|c|c|c|}
\hline & January & March & May & July \\
\hline & \multicolumn{4}{|c|}{ Plant height $(\mathrm{cm})$} \\
\hline Acerola Roxinha & $131 \mathrm{Aa}$ & $137 \mathrm{Ba}$ & $148 \mathrm{Ba}$ & $150 \mathrm{BCa}$ \\
\hline Acerola Sertaneja & $129 \mathrm{Ab}$ & $128 \mathrm{Bb}$ & $144 \mathrm{Ba}$ & $152 \mathrm{BCa}$ \\
\hline Banana & $84 * \mathrm{Bc}$ & $115 \mathrm{Bb}$ & $145 \mathrm{Ba}$ & $147 \mathrm{BCa}$ \\
\hline Cajá & $130 \mathrm{Ab}$ & $151 \mathrm{ABab}$ & $169 \mathrm{Ba}$ & $151 \mathrm{BCab}$ \\
\hline Cashew CCP76 & $94 \mathrm{Bb}$ & $105 \mathrm{Bb}$ & $140 \mathrm{Ba}$ & $155 \mathrm{BCa}$ \\
\hline Cashew EMB51 & $129 \mathrm{Ab}$ & $148 \mathrm{Bb}$ & $192 \mathrm{ABa}$ & $180 \mathrm{Ba}$ \\
\hline Coconut & $112 \mathrm{Bb}$ & $133 \mathrm{Bb}$ & $171 \mathrm{Ba}$ & $132 \mathrm{Cb}$ \\
\hline \multirow{2}{*}{ Red guava } & $165 \mathrm{Ab}$ & $185 \mathrm{Ab}$ & $226 \mathrm{Aa}$ & $231 \mathrm{Aa}$ \\
\hline & \multicolumn{4}{|c|}{ Canopy perimeter $(\mathrm{cm})$} \\
\hline Acerola Roxinha & $600 \mathrm{ABb}$ & $638 \mathrm{ABab}$ & $688 \mathrm{Ba}$ & $665 \mathrm{Bab}$ \\
\hline Acerola Sertaneja & $450 \mathrm{Bb}$ & $521 \mathrm{Bab}$ & $572 \mathrm{Ba}$ & $525 \mathrm{Cab}$ \\
\hline Banana & $613 \mathrm{ABc}$ & $713 \mathrm{Ab}$ & $878 \mathrm{Aa}$ & $407 \mathrm{CDd}$ \\
\hline Cajá & $313 \mathrm{Ca}$ & $345 \mathrm{Ca}$ & $281 \mathrm{Da}$ & $39 \mathrm{~Eb}$ \\
\hline Cashew CCP76 & $280 \mathrm{Cb}$ & $331 \mathrm{Cb}$ & $444 \mathrm{Ca}$ & $491 \mathrm{Ca}$ \\
\hline Cashew EMB51 & $412 \mathrm{BCc}$ & $495 \mathrm{Bb}$ & $579 \mathrm{BCa}$ & $587 \mathrm{BCa}$ \\
\hline Coconut & $482 \mathrm{Bb}$ & $533 \mathrm{Bb}$ & $616 \mathrm{Ba}$ & $356 \mathrm{Dc}$ \\
\hline \multirow{2}{*}{ Red guava } & $650 \mathrm{Ac}$ & $746 \mathrm{Ab}$ & $863 \mathrm{Aa}$ & $830 \mathrm{Aab}$ \\
\hline & \multicolumn{4}{|c|}{ Canopy volume $\left(\mathrm{m}^{3}\right)$} \\
\hline Acerola Roxinha & $2.53 \mathrm{Cb}$ & $3.10 \mathrm{BCab}$ & $4.00 \mathrm{Ca}$ & $3.77 \mathrm{Ba}$ \\
\hline Acerola Sertaneja & $1.48 \mathrm{CDB}$ & $1.95 \mathrm{Cab}$ & $2.84 \mathrm{CDa}$ & $2.55 \mathrm{Ba}$ \\
\hline Banana & $2.68 \mathrm{Bb}$ & $1.73 \mathrm{Cc}$ & $3.28 \mathrm{CDa}$ & $0.81 \mathrm{Cc}$ \\
\hline Cajá & $0.80 \mathrm{Dab}$ & $1.31 \mathrm{Ca}$ & $1.32 \mathrm{Da}$ & $0.14 \mathrm{Cb}$ \\
\hline Cashew CCP76 & $0.73 \mathrm{Db}$ & $1.11 \mathrm{Cb}$ & $2.44 \mathrm{Da}$ & $2.95 \mathrm{Ba}$ \\
\hline Cashew EMB51 & $1.45 \mathrm{CDb}$ & $2.28 \mathrm{BCb}$ & $3.80 \mathrm{Ca}$ & $3.72 \mathrm{Ba}$ \\
\hline Coconut & $2.27 \mathrm{Cc}$ & $3.50 \mathrm{Bb}$ & $6.61 \mathrm{Ba}$ & $1.24 \mathrm{Cc}$ \\
\hline Red guava & $4.20 \mathrm{Ac}$ & $5.77 \mathrm{Ab}$ & $9.16 \mathrm{Aa}$ & $8.70 \mathrm{Aa}$ \\
\hline
\end{tabular}

Lower case letters compare the variables in the rows and uppercase letters compare values in the columns, by PDIFF.

Canopy height: $p_{\text {fruit }}=0.0003$ and $\mathrm{MSE}_{\text {frui }}=12.00 ; p_{\text {period }}<0.0001$ and $\mathrm{MSE}_{\text {period }}=4.80 ; p_{\text {fruit xperiod }}=0.0003$ and $\mathrm{MSE}_{\text {fruit x period }}=13.70$.

Canopy perimeter: $p_{\text {fruit }}<0.0001$ and $\mathrm{MSE}_{\text {fruit }}=45.8 ; p_{\text {period }}<0.0001$ and $\mathrm{MSE}_{\text {period }}=18.27 ; p_{\text {fruit xperiod }}<0.0001$ and $\mathrm{MSE}_{\text {fruit } \mathrm{x} \text { period }}=51.7$.

Canopy volume: $p_{\text {fruit }}<0.0001$ and $\mathrm{MSE}_{\text {fruit }}=0.3989 ; p_{\text {period }}<0.0001$ and $\mathrm{MSE}_{\text {period }}=0.1940$; $p_{\text {fruit xperiod }}<0.0001$ and $\mathrm{MSE}_{\text {fruit x period }}=0.5966$.

Coconut trees, in spite of intermediate growth, had a marked drop in canopy volume between the assessments performed in May and July, from 6.61 to $1.24 \mathrm{~m}^{3}(p<0.0001)$, mainly due to the reduction of the canopy perimeter $(616$ to $356 \mathrm{~cm}$, from May to July) (Table 1). Among the factors that interfere with the development of the coconut tree, water deficiency is a frequently mentioned factor, mostly because the root system of this species is relatively close to the soil surface, making the tree highly vulnerable to water stress. In an experiment by Azevedo et al. (2006), during the production phase, $100 \%$ of the coconut palms roots were concentrated in the upper $100 \mathrm{~cm}$ of the soil layer, with the following distribution: $8 \%$ at $0-0.2 \mathrm{~m}, 32 \%$ at $0.2-0.4 \mathrm{~m}, 24 \%$ at $0.4-0.6 \mathrm{~m}, 15 \%$ at $0.6-0.8 \mathrm{~m}$, and $8 \%$ at $0.8-1.0 \mathrm{~m}$. During the development phase, these values were even lower. This fact may explain the similar responses of coconut trees compared to those of banana trees, namely a reduction in the canopy perimeter and height between May and July, from 171 to $134 \mathrm{~cm}$, which culminated in a reduction of canopy volume (Table 1). Banana and coconut trees demonstrated great dependence on irrigation in the off season, especially in the establishment phase, since they showed a dramatic decrease in growth as the dry season approached.

Cashew CCP76 had shorter plants with a smaller canopy diameter and, consequently, a smaller canopy volume as compared with the other species. This response may be related to the genetic of the plant; however, it may have been affected by the high need for initial replantation, due to the high mortality, reducing the mean values. This need for replantation of seedlings during the second experimental year, both by cashew CCP76 and EMB51, might result in a delayed entry of animals in the area and a delayed fruit production. Cashew CCP76 demonstrated a potential need for monitoring and labor when implemented in integrated systems compared with the other fruit trees.

Despite being a tall tree and having a wide canopy in the reproductive stage, the cajá is a deciduous species which, besides of the abscission of 
leaves, flowers, and fruits, has some branches that also senesce, remaining completely or partially canopy-less, as reported by Silva, Martins and Oliveira (2009). Precisely because of this characteristic, the cajá trees had the smallest canopies among the species, both in volume and diameter (Table 1). In the months with the optimal climatic conditions for plant growth (January to May), when all species displayed evolution for the canopy perimeter trait, the cajá tree did not evolve as the other species did $(313 \mathrm{~cm}$ in January and $281 \mathrm{~cm}$ in May). In July, there was an intense leaf fall and a dramatic reduction of canopy perimeter and volume (39 $\mathrm{cm}$ and $0.14 \mathrm{~m}^{3}$, respectively).

Although the guava trees stood out in terms of size, they had not the highest leaf area index (LAI) (1.34) $(p<0.0001)$ or light interception (\%LI)
$(62.0 \%)(p<0.0001)$ values; these were found for the acerola cultivars (Figure 1). The Acerola varieties Roxinha and Sertaneja (1.92) had the highest LAI values, whereas the LI of Acerola Roxinha $(74.6 \%)$ was highest. This fact demonstrates that light interception is more closely related to the porosity of the canopy than to its volume. Cajá and cashew CCP76, in addition to presenting the lowest growth rates among the species, also displayed the lowest values for LAI (1.05). The cajá trees also showed the lowest LI values (46.5\%), due to the smaller number of leaves distributed across the canopy. In terms of LI values, the coconut palms did not differ from cashew CCP76 (54.4\%) and, along with the cajá tree, they were the species with the lowest LI values or, indirectly, the most porous canopies.

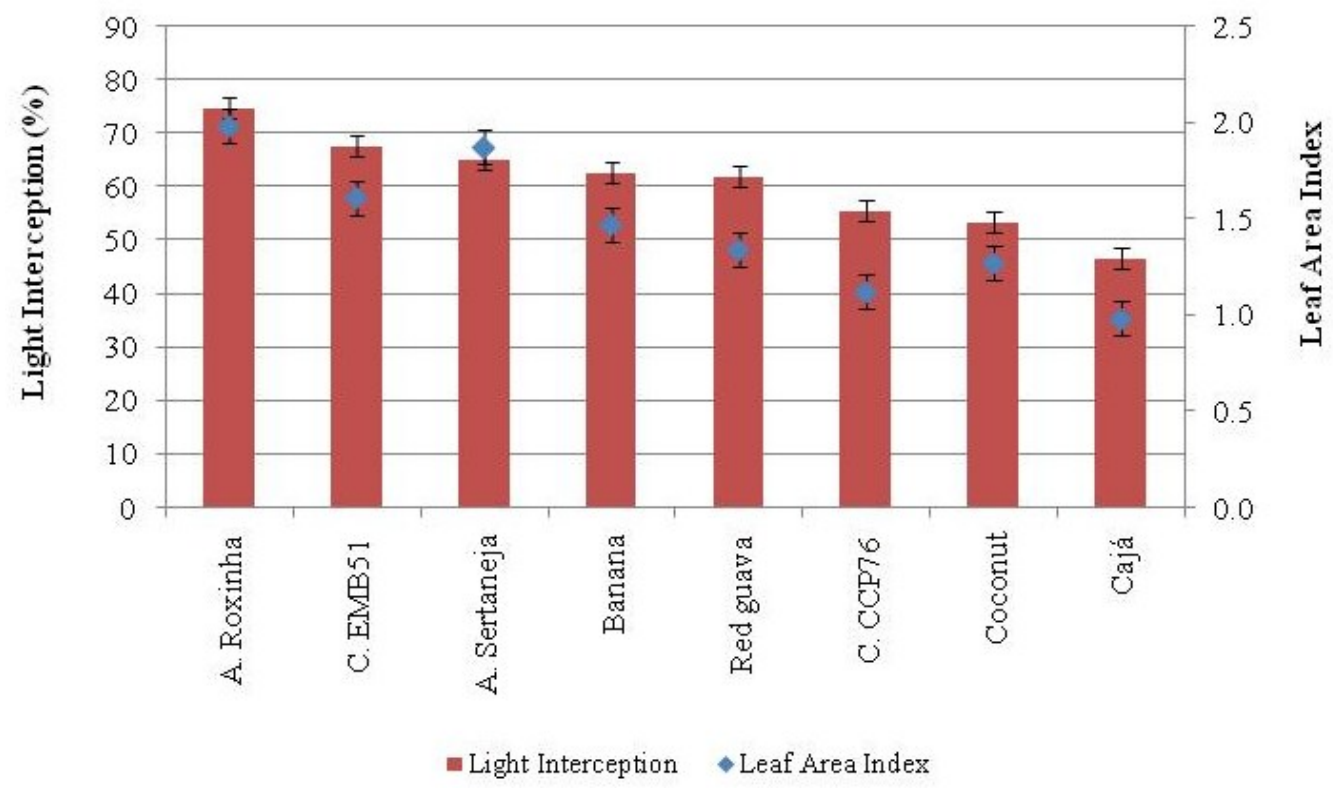

Figure 1. Leaf area index and light interception in 21-month-old fruit trees in silvopastoral systems, with their respective error bars.

Leaf area index and light interception values obtained in January (1.16 and $56.5 \%$, respectively) $(p<0.0001)$ were lower than those found in February, March, April, and May (1.51 and 57.91\%, 1.62 and $67.09 \%, 1.62$ and $63.56 \%$, and 1.52 and $61.08 \%$, respectively). The LAI decreased again in June (59.19\%), and the LI in May (1.52).

A dramatic reduction of LI and LAI was observed in March due to maintenance pruning of acerola and guava trees. Acerola Roxinha had a proportional reduction of LAI of the order of $20 \%$ and of $9 \%$ in LAI. Acerola Sertaneja had an even greater decrease, $26.5 \%$ for LAI and $5 \%$ for LI. The guava tree had a $20 \%$ decrease in its LAI values, but its LI was apparently not strongly affected, increasing only by $12 \%$. The other species did not require pruning and thus, there was a gradual progression in LI and LAI in this period.

In March, the highest LAI values $(p<0.0001)$ were found in most of the species that were not pruned, mainly due to the greater accumulated precipitation from the previous months. However, as the dry season drew near, beginning in May/June, these rates decreased until the rains ceased completely.

At the end of the collection period, acerola Roxinha displayed the highest LAI and LI values (Figure 1), indicating that it is a plant with a denser canopy, but lower porosity, due to the high amount of light intercepted by its canopy and the reduced luminosity on the forage sward. This high canopy density was coupled with a low plant height and a difficulty to increase the canopy skirt. This canopy-architecture characteristic may compromise the viability of this species for use in silvopastoral systems; because the canopy is too close to the soil level, this species might not be able to provide adequate shade. In addition, it might be more 
vulnerable to browsing by animals.

A large number of studies addressing competition for light only analyzed the variation in light amounts available to plants. However, not only the amount of light affects the development of plants under the canopy, but quality has also been pointed out as one of the important factors. This alteration in the quality of incident light available for the forage sward may be a result of the differential absorption of the wavelengths of light that reach the tree component (BALLARÉ; CASAL, 2000). Photosynthetic organisms contain chlorophyll, which absorbs wavelengths ranging from blue (400-500 $\eta \mathrm{m})$ to red (600-700 $\eta \mathrm{m})$, reflecting green (500-600 $\eta \mathrm{m})$. The red and blue radiations are the most efficient ones to optimize several desirable physiological responses in plants, whereas the wavelength of the far-red light (730-740 $\eta \mathrm{m})$ are hardly absorbed by plants, dissipating by reflection (TAIZ; ZEIGER, 2010).
Guava trees allowed a larger amount of the blue wavelength, $464 \eta \mathrm{m}$, to reach the forage sward $(p<0.0001)$ (Table 2). Cashews CCP67 and EMB51, cajá, and acerola Sertaneja were the species that most significantly filtrated this wavelength, preventing it from penetrating their canopies and reducing its availability to lower plants. The other species allowed an intermediate quantity of this wavelength to reach the lower sward. February and March were the months that provided the greatest incidence of this wavelength $(p<0.0001)$ for most species, decreasing gradually until June and then increasing its availability again in July. There were peaks in the March assessment for the guava and coconut trees, with values stabilizing in April. The banana tree showed similar responses in July. There was no difference in availability for the blue wavelength under the cajá tree canopy during the evaluated period (Table 2).

Table 2. Blue wavelength (464 $\mathrm{\eta m}$ ) under canopy fruit tree species in silvopastoral systems during the experimental period.

\begin{tabular}{|c|c|c|c|c|c|c|c|c|c|c|c|c|}
\hline \multirow[b]{3}{*}{ Acerola Roxinha } & \multicolumn{12}{|c|}{ Blue wavelength (waves s ${ }^{-1}$ ) } \\
\hline & \multicolumn{2}{|l|}{ Feb } & \multicolumn{2}{|c|}{ March } & \multicolumn{2}{|c|}{ April } & \multicolumn{2}{|c|}{ May } & \multicolumn{2}{|c|}{ June } & \multicolumn{2}{|c|}{ July } \\
\hline & 37800 & $\mathrm{Aa}$ & 24134 & $\mathrm{Cb}$ & 3477 & $\mathrm{Ac}$ & 3981 & Ac & 2448 & $\mathrm{Bc}$ & 11290 & $\mathrm{Bc}$ \\
\hline Acerola Sertaneja & 25442 & $\mathrm{Ba}$ & 15345 & $\mathrm{Cab}$ & 8133 & $\mathrm{Ab}$ & 3660 & $\mathrm{Ab}$ & 5152 & $\mathrm{ABb}$ & 5204 & $\mathrm{Bb}$ \\
\hline Banana & 16243 & $\mathrm{BCb}$ & 18477 & $\mathrm{CDb}$ & 3402 & Ac & 4729 & Ac & 11993 & $\mathrm{Abc}$ & 33789 & $\mathrm{Aa}$ \\
\hline Cajá & 12599 & $\mathrm{Ca}$ & 6649 & $\mathrm{Da}$ & 11495 & $\mathrm{Aa}$ & 6475 & $\mathrm{Aa}$ & 8640 & $\mathrm{ABa}$ & 6341 & $\mathrm{Ba}$ \\
\hline Cashew CCP76 & 32555 & $\mathrm{ABa}$ & 21432 & $\mathrm{Ca}$ & 6142 & $\mathrm{Ab}$ & 4821 & $\mathrm{Ab}$ & 4599 & $\mathrm{ABb}$ & 6070 & $\mathrm{Bb}$ \\
\hline Cashew EMB51 & 18565 & $\mathrm{BCa}$ & 14083 & $\mathrm{Dab}$ & 6820 & $\mathrm{Ab}$ & 2908 & $\mathrm{Ab}$ & 5691 & $\mathrm{ABb}$ & 3664 & $\mathrm{Bb}$ \\
\hline Coconut & 12841 & $\mathrm{Cb}$ & 33801 & $\mathrm{Ba}$ & 4007 & $\mathrm{Ab}$ & 4878 & $\mathrm{Ab}$ & 5276 & $\mathrm{ABb}$ & 8843 & $\mathrm{Bb}$ \\
\hline Red guava & 34488 & $\mathrm{Ab}$ & 63119 & $\mathrm{Aa}$ & 7935 & Ac & 4679 & Ac & 7271 & $\mathrm{ABc}$ & 10767 & $\mathrm{Bc}$ \\
\hline
\end{tabular}

Lower case letters compare the variables in the rows and uppercase letters compare values in the columns, by PDIFF. $p_{\text {fruit }}<0.0001$ and $\mathrm{MSE}_{\text {fruit }}=1660 ; p_{\text {period }}<0.0001$ and $\mathrm{MSE}_{\text {period }}=1784 ; p_{\text {fruit xperiod }}<0.0001$ and $\mathrm{MSE}_{\text {fruit } x \text { period }}=7408$.

Because of its low LAI value, the guava tree canopy could intercept a small amount of the blue wavelength (464 ๆm) (Table 1), thus representing the species that allowed the largest amount of this wavelength to reach the forage sward.

February and March, the months during which the tree component still showed growth, allowed a greater passage of the blue wavelength, thereby providing a larger amount to the lower sward (Table $2)$. As the fruit trees grew, the filtration of blue light increased. Because of its reduced canopy, the banana tree allowed a greater passage of blue light in July.

Plants under the canopies of the trees perceive this alteration in R: FR ratio and can adjust their physiology and morphology through a phytochrome response. Under a low R: FR ratio, plants display a rapid increase in stem and petiole elongation rates (BATSCHAUER, 1998). The higher the R: FR ratio, the better the light quality, since it is richer in red wavelengths.

The red: far-red (R:FR) ratio varied according to the species $(p=0.0001)$ and month of assessment $(p<0.0001)$ (Table 3). Guava, cajá, and banana trees were the species that showed the highest average R: FR ratios (0.9216), i.e., better light quality was available to stimulate the growth of the plants under their canopies. The lowest values were found in cashew EMB51 and acerola Sertaneja (0.7356), which impaired plant growth under their canopy. The other species had intermediate values (0.7995). July was the month that provided the highest results for this variable, due to the drought and reduction of leaves. Cashew CCP76 and acerola Sertaneja did not change the light quality over the months, whereas the other species presented an improvement between January and July. This 
variable was notably increased in the banana tree between May and July, allowing plant growth under the canopies in this period as long as water was not a limiting factor. It must be considered that greater plant growth under the canopies has advantages and disadvantages. If the plant material is grass, it can be harvested; if it consists of weeds, requiring maintenance and weeding at a higher frequency.

Table 3. Red/far red ratio under the canopy of different fruit tree species in silvopastoral systems during the experimental period.

\begin{tabular}{|c|c|c|c|c|c|c|c|c|c|c|c|}
\hline \multirow[b]{3}{*}{ Acerola Roxinha } & \multicolumn{11}{|c|}{ Red/far red ratio } \\
\hline & \multicolumn{2}{|c|}{ Feb } & \multicolumn{2}{|c|}{ March } & \multicolumn{2}{|c|}{ April } & \multicolumn{2}{|c|}{ May } & \multicolumn{2}{|c|}{ June } & July \\
\hline & 0.83 & Abab & 0.82 & $\mathrm{Bab}$ & 0.71 & $\mathrm{Bb}$ & 0.65 & $\mathrm{ABb}$ & 0.69 & $\mathrm{Bb}$ & $1.02 \mathrm{Ba}$ \\
\hline Acerola Sertaneja & 0.76 & Aba & 0.64 & $\mathrm{BCa}$ & 0.87 & $\mathrm{ABa}$ & 0.64 & $\mathrm{ABa}$ & 0.72 & $\mathrm{Ba}$ & $0.80 \mathrm{Ca}$ \\
\hline Banana & 0.72 & $\mathrm{Abc}$ & 0.91 & $\mathrm{ABbc}$ & 0.44 & $\mathrm{Cd}$ & 0.50 & Bcd & 1.08 & $\mathrm{Ab}$ & 1.70 \\
\hline Cajá & 0.67 & $\mathrm{Bb}$ & 1.00 & $\mathrm{ABab}$ & 1.06 & $\mathrm{Aa}$ & 0.83 & $A a b$ & 1.04 & $\mathrm{Aa}$ & $1.03 \mathrm{Ba}$ \\
\hline Cashew CCP76 & 1.00 & $\mathrm{Aa}$ & 0.80 & $\mathrm{Ba}$ & 0.89 & $\mathrm{ABa}$ & 0.79 & $\mathrm{Aa}$ & 0.72 & $\mathrm{Ba}$ & 0.78 \\
\hline Cashew EMB51 & 0.83 & $\mathrm{ABa}$ & 0.53 & $\mathrm{Cb}$ & 0.85 & $\mathrm{ABa}$ & 0.73 & $\mathrm{ABab}$ & 0.78 & $\mathrm{Bab}$ & $0.71 \mathrm{Cab}$ \\
\hline Coconut & 0.82 & $\mathrm{ABab}$ & 0.92 & $\mathrm{ABab}$ & 0.57 & $\mathrm{BCb}$ & 0.62 & $\mathrm{ABb}$ & 0.75 & $\mathrm{Bb}$ & $1.02 \mathrm{Ba}$ \\
\hline Red guava & 0.88 & $\mathrm{ABb}$ & 1.16 & $\mathrm{Aa}$ & 0.89 & $\mathrm{ABab}$ & 0.81 & $\mathrm{Ab}$ & 0.91 & $\mathrm{ABab}$ & $1.14 \mathrm{Ba}$ \\
\hline
\end{tabular}

Lower case letters compare the variables in the rows and uppercase letters compare values in the columns, by PDIFF. $p_{\text {fruit }}<0.0001$ and $\mathrm{MSE}_{\text {fruit }}=0.037 ; p_{\text {period }}<0.0001$ e $\mathrm{MSE}_{\text {period }}=0.046 ; p_{\text {fruit xperiod }}=0.0003$, and $\mathrm{MSE}_{\text {fruit x period }}=0.186$.

July, a month characterized by intense drought and strong solar radiation in this region of Brazil, had the highest $\mathrm{R}$ : FR ratio during the experimental period (Table 3). The extremely low soil water availability negatively impacted plant growth, increasing senescence and loss of leaves and allowing the passage of light of better quality through the tree canopy.

Regarding the decrease in LAI and LI of the banana tree between May and June, due to the dry season, there was an increase in the availability of blue light (Table 2) under the canopy, in addition to an improvement in the R: FR ratio (Table 3), providing better plant growth conditions under the canopies. However, this growth could only be effectively accomplished in the presence of the other growth factors. Several factors are related to this increase in the quality of light under the tree canopy, such as tree height, tree vertical structure, number and distribution of branches, leaf density, area, leaf angle, and leaf reflectance (FEY; MALAVASI; MALAVASI, 2015), all of which are severely affected by the dry season.

The guava tree had its peak R: FR ratio (Table 3) and blue light availability (Table 2) in March, possibly as a result of the formative pruning performed in this period prior to assessment. Pruning led to a sharp decrease in the LAI values of the fruit trees, allowing higher quality light to reach the forage sward, at times even causing saturation of the reading device, i.e., presenting the complete sunlight profile without any filtering.
The amount of available sunlight and the R: FR ratio are the factors that most limit the growth and development of plants (TAIZ; ZEIGER, 2010). Under intense shading conditions, many authors have reported decreased plant production, in which competition for light is a limiting factor to forage production under the tree canopy in silvopastoral systems (PACIULLO et al., 2011).

Cajá, cashew EMB51, coconut, and guava trees were the species with greatest total dry matter accumulation under their canopies $\left(89.5 \mathrm{~g} \mathrm{~m}^{-2}\right)$. Acerola Sertaneja, banana, and cashew CCP76 fitted the category of intermediate species $\left(80 \mathrm{~g} \mathrm{~m}^{-2}\right)$, whereas acerola Roxinha was the species with the lowest total dry matter accumulation under its canopy (70 $\mathrm{g} \mathrm{m}^{-2}$ ) (Table 4).

The capacity of fruit trees to suppress plant growth can be explained by architectonic differences in the canopy of each fruit tree species. Denser canopies intercept larger amounts of light and change its quality with a greater intensity, leading to less light availability to the forage sward, as was the case for acerola Roxinha, a species with one of the largest canopies and highest LAI and LI values, which resulted in one of the lowest R: FR ratios; this, in turn, provided a greater suppression of forage growth under its canopy. This fact demonstrates that one of the decisive factors for the growth and development of a forage plant in a silvopastoral system is the radiation that manages to penetrate the canopy of the tree component and reaches the lower stratum (FEY; MALAVASI; MALAVASI, 2015). 
Table 4. Total dry matter accumulation under canopy fruit tree species in silvopastoral systems during the experimental period.

\begin{tabular}{|c|c|c|c|c|c|c|c|c|c|}
\hline \multirow[b]{3}{*}{ Acerola Roxinha } & \multicolumn{9}{|c|}{ Total dry matter accumulation $\left(\mathrm{g} \mathrm{m}^{-2}\right)$} \\
\hline & \multicolumn{2}{|c|}{ Jan } & March & \multicolumn{2}{|c|}{ April } & \multicolumn{2}{|c|}{ May } & \multicolumn{2}{|c|}{ Mean } \\
\hline & 62 & $\mathrm{Cab}$ & $92 \mathrm{Ba}$ & 97 & $\mathrm{Aa}$ & 32 & $\mathrm{Bb}$ & 70 & \\
\hline Acerola Sertaneja & 172 & $\mathrm{Aa}$ & $97 \mathrm{Bb}$ & 40 & $\mathrm{Bc}$ & 19 & $\mathrm{Bc}$ & 83 & $\mathrm{AB}$ \\
\hline Banana & 79 & $\mathrm{BCa}$ & $94 \mathrm{Ba}$ & 85 & $\mathrm{Aa}$ & 56 & $\mathrm{ABa}$ & & $\mathrm{AB}$ \\
\hline Cajá & 105 & $\mathrm{Ba}$ & $90 \mathrm{Ba}$ & 90 & $\mathrm{Aa}$ & 36 & $\mathrm{Bb}$ & 80 & $\mathrm{AB}$ \\
\hline Cashew CCP76 & 134 & $\mathrm{ABa}$ & $90 \mathrm{Bb}$ & 68 & $\mathrm{ABb}$ & 77 & $\mathrm{Ab}$ & 92 & A \\
\hline Cashew EMB51 & 78 & $\mathrm{BCb}$ & $141 \mathrm{Aa}$ & 81 & $\mathrm{ABb}$ & 36 & $\mathrm{Bc}$ & 86 & A \\
\hline Coconut & 127 & $\mathrm{ABa}$ & $135 \mathrm{Aa}$ & 59 & $\mathrm{ABb}$ & 39 & $\mathrm{Bb}$ & 90 & A \\
\hline Red guava & 145 & $\mathrm{ABa}$ & $140 \mathrm{Aa}$ & 47 & $\mathrm{Bb}$ & 29 & $\mathrm{Bb}$ & 90 & A \\
\hline
\end{tabular}

Lower case letters compare the variables in the rows and uppercase letters compare values in the columns, by PDIFF.

$p_{\text {fruit }}<0.0001$ and $\mathrm{MSE}_{\text {fruit }}=27.05 ; p_{\text {period }}<0.0001$ e $\mathrm{MSE}_{\text {period }}=16.71 ; p_{\text {fruit xperiod }}<0.0001$, and
$\mathrm{MSE}_{\text {fruit x period }}=47.26$.

At the beginning of the experimental period, all plants allowed plant growth under their canopies, as they were small-sized trees. In the period from 2014, January to March, plant growth was intense due to the high availability of growth factors (Table 4), mainly water. In the months of April and May, as the dry period drew near, a reduction was observed in precipitation and available water; consequently, plant dry matter accumulation decreased, even though the quantity and quality of light had a positive influence as the months passed, demonstrating a great impact of seasonality on plant production. The exception was the banana tree; its dry matter accumulation was not affected during the experimental period, possibly because in the beginning of the experimental period, it did not significantly compete for water with the lower plant stratum because of its superficial roots. As the dry season approached, with a reduction of canopy diameter and volume, the banana tree did not significantly compete for light.

Cajá, cashew EMB51, coconut, and guava were the species that provided greatest total dry matter accumulation under their canopies (Table 4), demonstrating lower forage growth suppression capacity than the other species. Except for cashew EMB51, these species allowed a larger quantity and better quality of light to reach the forage sward, i.e., light that contained a higher R: FR ratio (Table 3). Rozados-Lorenzo, González-Hernández and Silva-Pando (2007) have also detected this inverse relationship between the LAI values of trees and the pasture production in a silvopastoral system.

Acerola Sertaneja, banana, and cashew CCP76 showed intermediate suppression of plant growth (Table 4), due to alteration in the quantity of light (acerola Sertaneja, banana, and cashew CCP76) and in the quality of light (acerola Sertaneja).

Another factor that led to greater dry matter accumulation under the canopy of cashews EMB51 and CCP76, coconut, acerola Sertaneja, and cajá was the lower canopy diameter. The fruit trees did not occupy a large portion of the collected plant area $\left(3.14 \mathrm{~m}^{2}\right)$, which was mostly under full sun or under lower influence of the canopy shade that allowed its free growth.

Given the limiting climatic conditions in the month of July, there was no more forage left for collection under the canopy of the trees, indicating the end of the evaluation period.

\section{CONCLUSIONS}

Guava trees have a great potential to be used in integrated systems, with a rapid initial phase and a good canopy architecture, providing shade and adequate plant growth under their canopies.

Acerola Roxinha has adequate initial growth, with interesting growth control of other plants under the canopy. However, its specific architecture restricts its use in silvopastoral systems. Acerola Sertaneja, on the other hand, appears to be more promising, as it features the same characteristics and a better canopy architecture.

The cajá tree showed fast initial establishment and good canopy architecture, but its deciduousness during the hottest times of the year should be taken into account in the first years of implementation.

Because of their superficial root systems, the coconut and banana trees require greater care during the dry season, with frequent irrigation.

Cashew CCP76 seems to be suitable for integrated systems due to its rapid initial growth and good canopy architecture. However, its high initial mortality must be considered, as it may delay the access of animals to the area and fruit production, requiring greater attention in this regard. Variety EMB51, in turn, is a more promising cashew option for silvopastoral systems, with rapid establishment and good canopy architecture. 


\section{REFERENCES}

AZEVEDO, P. V. et al. Water-use efficiency of dwarf-green coconut (Cocos nucifera L.) orchards in northeast Brazil. Agricultural water management, Amsterdam,v. 84, n. 3, p. 259-264, 2006.

BALBINO, L. C.; BARCELlOS, A. O.; STONE, L. F. Marco referencial: integração lavoura-pecuária-floresta (iLPF). Brasília, DF: Embrapa, 2011.130 p.

BALLARÉ, C. L.; CASAL, J. J. Light signals perceived by crop and weed plants. Field Crops Research, Amsterdam, v. 67, n. 2, p. 149-160, 2000.

BATSCHAUER, A. Photoreceptors of higher plants. Planta, Berlin,v. 206, n. 4, p. 479-492, 1998.

FEY, R.; MALAVASI, U. C.; MALAVASI, M. M. Silvopastoral system: a review regarding the family agriculture. Revista de Agricultura Neotropical, Cassilândia, v. 2, n. 2, p. 26-41, 2015.

\section{INSTITUTO}

\section{NACIONAL}

$\mathrm{DE}$ METEREOLOGIA - INMET. Banco de dados meteorológicos para Ensino e Pesquisa. Disponível em: <http://www.inmet.gov.br/portal/ index.php?r=bdmep/bdmep>. Acesso em: 20 set. 2014.

MELOTTO, A.; NICODEMO, M. L.; BOCCHESE, R. A. Sobrevivência e crescimento inicial em campo de espécies florestais nativas do Brasil Central indicadas para Sistemas Silvipastoris. Revista Árvore, Viçosa ,v. 33, n. 3, p. 425-432, 2009.

PACIULLO, D. S. C. et al. Performance of dairy heifers in a silvopastoral system. Livestock Science, Amsterdam, v. 141, n. 2, p. 166-172, 2011.

PAIVA, J. R. et al. Polyculture with different fruit species of economic value. Ciência e Agrotecnologia, Lavras, v. 30, n. 1, p. 81-87, 2005.

ROZADOS-LORENZO, GONZÁLEZ-HERNÁNDEZ,

M. J.; SILVA-PANDO, F. J. Pasture production under different tree species and densities in an Atlantic silvopastoral system. Agroforestry Systems, Dordrecht, v. 70, n. 1, p. 53-62, 2007.

SILVA, A. J. P. D. et al. Estimating water application efficiency for drip irrigation emitter patterns on banana. Pesquisa Agropecuária Brasileira, Brasília, v. 44, n. 7, p. 730-737, 2009.

SILVA, E. F. D.; MARTINS, L. S. S.; OLIVEIRA, V. R. D. Diversity and genetic struture in cajá tree (spondias mombin 1.) populations in northeastern
Brazil. Revista Brasileira de Fruticultura, Jaboticabal, v. 31, n. 1, p. 171-181, 2009.

SOIL SURVEY STAFF. Soil taxonomy: A basic system of soil classification for making and interpreting soil surveys. 2nd edition. Washington, DC: US Government Printing Office, 1999. 436 p.

SOUZA, F. X. et al. Crescimento e desenvolvimento de clones de cajazeira cultivados na Chapada do Apodi, Ceará. Revista Brasileira de Fruticultura, Jaboticabal, v. 28, n. 3, p. 414-420, 2006.

TAIZ, L.; ZEIGER, E. Plant Physiology. 6th edition. Sunderland, MA: Sinauer Associates, $2010.782 \mathrm{p}$.

TUCKER, C. B.; ROGERS, A. R.; SCHÜTZ, K. E. Effect of solar radiation on dairy cattle behaviour, use of shade and body temperature in a pasture-based system. Applied Animal Behaviour Science, Amsterdam, v. 109, n. 2, p. 141-154, 2008. 